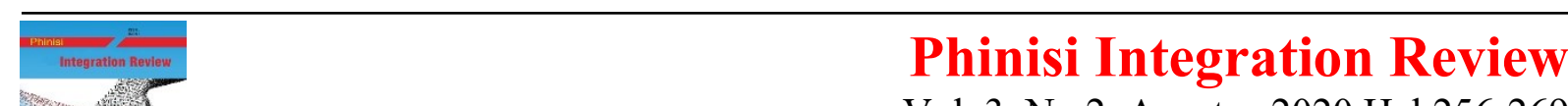

Vol. 3, No.2, Agustus 2020 Hal 256-269

Website: http://ojs.unm.ac.id/pir

p-ISSN: 2614-2325 dan e-ISSN: 2614-2317

DOI: https://doi.org/10.26858/v3i2.14904

\title{
Implementasi Penguatan Pendidikan Karakter di Madrasah Tsanawiyah Negeri 1 Jeneponto
}

\author{
Sahabuddin ${ }^{1}$, Hasnawi Haris ${ }^{2}$, Hamsu Abdul Gani ${ }^{3}$ \\ ${ }^{1}$ Madrasah Tsanawiyah Negeri 1 Jeneponto, Universitas Negeri Makassar, Indonesia \\ ${ }^{23}$ Ilmu sosial, Universitas Negeri Makassar, Indonesia \\ ${ }^{1}$ Email: pashamtsn73@gmail.com
}

\begin{abstract}
Abstrak. Penelitian Ini bertujuan (i) Untuk mengetahui bagaimana implementasi penguatan pendidikan nilai - nilai karakter ke dalam mata pelajaran Agama dan PPKn di MTs Negeri 1 Jeneponto, (ii) Untuk mengetahui bagaimana implementasi penguatan pendidikan nilai-nilai karakter melalui pengembangan diri di MTs Negeri 1 Jeneponto, dan (iii) Untuk mengetahui apa yang menjadi faktor pendukung dan penghambat pelaksanaan penguatan pendidikan nilai-nilai karakter di MTs Negeri 1 Jeneponto.Jenis Penelitian yang digunakan pada penelitian ini adalah jenis penelitian kualitatif. Subjek penelitian terdiri dari (i) para Tenaga pendidik PPKn, dan (ii) para Tenaga Pendidik Agama. Pada penelitian ini menggunakan teknik pengambilan sampel dengan metode Purposive Sampling. Hasil penelitian ini menunjukan bahwa Implementasi penguatan pendidikan nilai-nilai karakter melalui pengintegrasian ke dalam mata pelajaran Agama dan PPKn di MTs Negeri 1 Jeneponto mencakup beberapa aspek diantaranya (i) Mampu menanamkan nilai-nilai kejujuran dan cinta tanah air antar sesama, (ii) membentuk rasa nasionalisme dan cinta tanah air antar sesama (iii) Implementasi Proses pembelajaran pendidikan karakter dalam mencapai tujuannya adalah dengan menyiapkan silabus, RPP dan memperhatikan rana afektif dan koknitif dalam proses pembelajaran, dan (iv) Memberikan motivasi terhadap para peserta didik dan mampu memberikan semacam penghargaan kepada mereka agar mampu meningkatkan minat peserta didik dalam proses pembelajaran. Pada Implementasi penguatan pendidikan nilai-nilai karakter melalui pengembangan diri di MTs Negeri 1 Jeneponto meliputi (i) Mampu memberikan pemahaman tentang wawasan kebangsaan dan keagamaan terhadap peserta didik dan mampu menjelaskan makna tentang Bhineka Tunggal Ika (ii) Tenaga pendidik mampu menerapkan metode pembelajaran dengan strategi memberikan pemahaman terhadap para peserta didik dengan kehidupan sosial mereka. (iii) tenaga pendidik mampu menanamkan rasa patriotisme terhadap para peserta didik.
\end{abstract}

Kata Kunci: Pendidikan Karakter, Peserta didik, Tenaga Pendidik.

Abstract. Madrasa as a vehicle for character education takes place the process of
transforming noble values through character education. Character education is a keyword
of the process of transforming noble values in Madrasas. Teachers become transformers of
noble values to students to become part of a civilized society. This study aims (i) to find
out how the implementation of the strengthening of character values education in the
subjects of Religion and PPKn in MTs Negeri 1 Jeneponto, (ii) To find out how the
implementation of strengthening the education of character values through self-
development in MTs Negeri 1 Jeneponto, and (iii) To find out what are the supporting and 
inhibiting factors in the implementation of the strengthening of character values education in MTs Negeri 1 Jeneponto.The type of research used in this study is the type of qualitative research. The research subjects consisted of (i) the PPKn educators, and (ii) the Religious Educators. In this study using a sampling technique with purposive sampling method. The results of this study indicate that the implementation of strengthening the education of character values through integration into the subjects of Religion and PPKn in MTs Negeri 1 Jeneponto includes several aspects including (i) Being able to instill the values of honesty and love of the motherland among others, (ii) forming a sense of nationalism and mutual love for the motherland (iii) Implementation of the character education learning process in achieving its goals is to prepare syllabi, lesson plans and pay attention to affective and positive shutter in the learning process, and (iv) Provide motivation to students and be able to give a kind of appreciation to them to be able to increase the interest of students in the learning process. In the implementation of strengthening the education of character values through self-development in MTs Negeri 1 Jeneponto include (i) Able to provide an understanding of national and religious insights for students and be able to explain the meaning of Unity in Diversity (ii) Educators are able to apply learning methods with strategies give students an understanding of their social life. (iii) educators are able to instill a sense of patriotism towards students.

Keywords: Character Education, Students, Educators.

Ini adalah artikel dengan akses terbuka dibawah licenci CC BY-NC-4.0 (https://creativecommons.org/licenses/by-nc/4.0/).

\section{PENDAHULUAN}

Undang-Undang Nomor 20 Tahun 2003 tentang Sistem Pendidikan Nasional pada Pasal 3 menyatakan bahwa pendidikan nasional berfungsi mengembangkan kemampuan dan membentuk karakter serta peradaban bangsa yang bermartabat dalam rangka mencerdaskan kehidupan bangsa. Pendidikan Nasional bertujuan untuk berkembangnya potensi peserta didik agar menjadi manusia yang beriman dan bertakwa kepada Tuhan Yang Maha Esa, berakhlak mulia, sehat, berilmu, cakap, kreatif, mandiri dan menjadi warga negara yang demokratis serta bertanggung jawab.

Berdasarkan fungsi dan tujuan pendidikan nasional, jelas bahwa pendidikan di setiap jenjang, termasuk di Madrasah harus diselenggarakan secara sistematis guna mencapai tujuan tersebut. Hal ini berkaitan dengan pembentukan karakter peserta didik sehingga mampu bersaing, beretika, bermoral, sopan santun dan berinteraksi dengan masyarakat.

Pembangunan di bidang pendidikan ke depan harus didasarkan pada paradigma pembangunan manusia Indonesia seutuhnya, yang berfungsi sebagai subyek dan obyek, yang memiliki kapasitas untuk mengaktualisasikan potensi

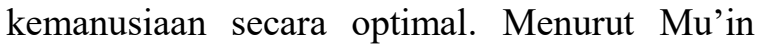

(2011 : 287), Pendidikan sebagai suatu proses seringkali memunculkan dua asumsi yang berbeda dalam kehidupan manusia yaitu (1). Pendidikan dianggap sebagai sebuah proses yang terjadi secara tidak disengaja atau berjalan secara alamiah. Dalam hal ini pendidikan bukanlah proses yang diorganisasi secara teratur, terencana, dan menggunakan metode-metode yang dipelajari serta berdasarkan aturan-aturan yang telah disepakati mekanisme penyelenggaraannya. (2). Pendidikan bisa dianggap sebagai proses yang terjadi secara sengaja, direncanakan, didesain, dan diorganisasi berdasarkan aturan yang berlaku. Dari pendapat tersebut seharusnya memang pendidikan harus direncanakan.

Apatah lagi dengan melihat fenomena yang terjadi saat ini, kondisi bangsa kita sedang sakit menurut Safii Maarif. Krisis moral melanda hampir semua elemen masyarakat. Hal itu dengan mudah diketahui karena setiap hari pemberitaan melalui berbagai media cetak atau elektronik, seperti surat kabar, televisi atau internet yang menyuguhkan berita kriminalitas, seperti korupsi, penyuapan, pembunuhan, perkosaan, perkelahian, penggunaan obat-obat terlarang, tawuran, kesenjangan sosial, ketidakadilan, perampokan, pelecehan seksual, penipuan dan fitnah terjadi dimana-mana. 
Bahkan tidak jarang kondisi seperti itu dapat disaksikan secara langsung di tengah-tengah masyarakat. Fakta lain menunjukkan pembangunan jati diri dan karakter bangsa semakin memudar, yang disebabkan antara lain kurangnya keteladanan, pemberitaan media cetak dan elektronik yang tidak mendidik.

Dengan melihat kondisi seperti di atas, maka untuk mengurangi degradasi karakter dan budaya bangsa, pendidikan dianggap sebagai solusi yang dapat mencegah (preventif) karena pendidikan dapat membangun generasi baru bangsa yang lebih baik. Pendidikan diharapkan dapat mengembangkan kualitas generasi muda bangsa dalam berbagai aspek yang dapat memperkecil dan mengurangi penyebab berbagai masalah karakter dan budaya bangsa. Menurut Fitri (2012 :17) sebagai bangsa yang sadar akan pentingnya karakter berbasis nilai dan etika tentunya seharusnya kita dalam mendidik harus mengajarkan nilai-nilai karakter sebagai bangsa yang jujur, santun, toleran, ramah, apa adanya dan menanamkan kembali nilai-nilai tersebut pada generasi bangsa, serta mengembangkan nilai-nilai lainnya yang tidak bertentangan dengan etika dan moral bangsa. Apabila Madrasah dan dunia pendidikan ingin berhasil dalam menanamkan karakter bangsa, perlu membangun budaya Madrasah (school culture). Hal tersebut perlu ditanamkan sejak dini, diantaranya melalui pendidikan karakter mulai dari pendidikan dasar. Dengan pendidikan karakter diharapkan dapat membentuk, menanamkan, memfasilitasi, dan mengembangkan nilai-nilai positif pada anak sehingga menjadi pribadi yang unggul dan bermartabat. Menurut Ratna Megawangi (dalam Gunawan, 2012 : 30) bahwa pendidikan karakter adalah untuk mengukir akhlak melalui proses knowing the good, loving the good, and acting the good, yakni suatu proses pendidikan yang melibatkan aspek kognitif, emosi, dan fisik, sehingga akhlak mulia bisa terukir menjadi habit of the mind, heart, and hands.

Namun hasil pengamatan awal didapatkan data oleh peneliti bahwa nilai-nilai karakter yang harus dikembangkan di Madrasahdan telah terintegrasi ke dalam beberapa mata pelajaran tersebut belum sepenuhnya terlaksana dengan baik. Masih banyaknya siswa yang mengaku kehilangan uang ataupun pulpen mengindikasikan bahwa bahwa nilai - nilai kejujuran di Madrasah ini masih perlu penguatan, bahkan di Madrasah ini pernah diadakan kantin kejujuran tapi pengelola kantin mengaku mengalami kerugian. Budaya LISA (lihat sampah ambil) yang diprogramkan pihak Madrasah belum terlaksana dengan baik karena masih banyaknya siswa yang membuang sampah sembarangan ataupun membiarkan sampah berserakan. Budaya gemar membaca (Literasi) yang juga menjadi program Madrasah ini juga belum terlaksana dengan baik karena masih banyak siswa yang tidak membawa buku bacaan ataupun membaca buku ketika hari gemar membaca (literasi) diadakan. Hal ini mengindikasikan bahwa diperlukan upaya dan komitmen bagi pendidik untuk lebih memberikan penguatan pelaksanaanpendidikan karakterbagi peserta didik. Nilai-nilai karakter yang perlu penguatan tersebut antara lain nilai jujur, kerja keras, kreatif, rasa ingin tahu, semangat kebangsaan, menghargai prestasi, peduli lingkungan, gemar membaca dan tanggung jawab.

Penguatan pendidikan karakter ke dalam mata pelajaran bisa dilakukan dengan cara memasukkan nilai-nilai karakter ke dalam silabus dan Rencana Pelaksanaan Pembelajaran (RPP) untuk selanjutnya pada saat guru melaksanakan pembelajaran di kelas, pendidikan nilai-nilai tersebut harus tercermin dalam kegiatan pembelajarana yang harus di barengi dengan praktek dalam kehidupan sehari - hari. Berdasarkan uraian di atas maka peneliti tertarik untuk mengadakan penelitian pada MTs Negeri 1 Jeneponto sebagai salah satu Madrasah unggulan dan sebagai salah satu Madrasah rujukan di Propinsi Sulawesi Selatan, khususnya mengenai Implementasi Penguatan Pendidikan Nilai-Nilai Karakter di Madrasah tersebut

\section{TINJAUAN PUSTAKA}

\section{A. Hakekat Pendidikan Karakter}

Undang-Undang Republik Indonesia Nomor 20 tahun 2003 tentang Sistem Pendidikan Nasional mengatur fungsi dan tujuan pendidikan nasional yang harus digunakan dalam mengembangkan upaya pendidikan di Indonesia. Pasal 3 Undang-undang Sistem Pendikan Nasional menyatakan, "Pendidikan nasional berfungsi mengembangkan dan membentuk watak serta peradaban bangsa yang bermartabat dalam rangka mencerdaskan kehidupan bangsa, bertujuan untuk berkembangnya potensi peserta didik agar menjadi manusia yang beriman dan bertakwa kepada Tuhan Yang Maha Esa, berakhlak mulia, sehat, berilmu, cakap, kreatif, 
mandiri, dan menjadi warga negara yang demokratis serta bertanggung jawab". Tujuan pendidikan nasional itu merupakan rumusan mengenai kualitas manusia Indonesia yang harus dikembangkan oleh setiap satuan pendidikan. Oleh karena itu, rumusan tujuan pendidikan nasional menjadi dasar dalam pengembangan pendidikan budaya dan karakter bangsa.

Berdasarkan Peraturan Presiden nomor 87 tahun 2017 tentang Penguatan Pendidikan (PPK) pasal 1 yang di maksud PPK adalah: Penguatan Pendidikan Karakter yang selanjutnya disingkat PPK adalah gerakan pendidikan di bawah tanggung jawab satuan pendidikan untukmemperkuat karakter peserta didik melaluiharmonisasi olah hati, olah rasa, olah pikir, dan olahraga dengan pelibatan dan kerja sama antara satuanpendidikan, keluarga, dan masyarakat sebagai bagiandari Gerakan Nasional Revolusi Mental (GNRM). (Pepres nomor 87, $2017: 2$ )

Secara terminologi (istilah) karakter diartikan sebagai sifat manusia pada umumnya yang bergantung pada faktor kehidupannya.Karakter adalah sifat kejiwaaan, akhlak, atau budi pekerti yang menjadi ciri khas seseorang atau sekelompok orang. Karakter merupakan nilai-nilai perilaku manusia yang berhubungan dengan Tuhan Yang Maha Esa, diri sendiri, sesama manusia, lingkungan dan kebangsaan yang terwujud dalam pikiran,sikap, perasaan, perkataan dan perbuatan berdasarkan norma-norma agama, hukum dan tata karma, budaya dan adat istiadat. Karakter dapat juga diartikan sama dengan akhlak dan budi pekerti sehingga karakter bangsa sama dengan akhlak bangsa atau budi pekerti sehingga karakter bangsa sama dengan akhlak bangsa atau budi pekerti bangsa. Menurut Fitri (2012 : 21) bangsa yang berkarakter adalah bangsa yang berakhlak dan berbudi pekerti. Sebaliknya, bangsa yang tidak berkarakter adalah bangsa yang tidak berakhlak atau tidak memiliki standar norma dan perilaku yang baik.

Menurut Gunawan (2012 : 24) pendidikan karakter adalah segala sesuatu yang dilakukan oleh guru, yang mampu mempengaruhi karakter peserta didik. Guru membantu membentuk watak peserta didik. Hal ini mencakup keteladanan bagaimana perilaku guru, cara guru berbicara atau menyampaikan materi, bagaimana guru bertoleransi dan berbagai hal terkait lainnya. Pendapat lain mengenai pendidikan karakter adalah Ratna Megawangi (Ardy Wiyani, 2012 : 42) bahwa pendidikan karakter adalah sebuah usaha untuk mendidik anak-anak agar dapat mengambil keputusandengan bijak dan mempraktikkan dalam kehidupan sehari-hari sehingga mereka dapat memberikan konstribusi positif kepada masyarakatnya. Menurut Saptono (2011 : 23) Pendidikan karakter adalah upaya yang dilakukan dengan sengaja untuk mengembangkan karakter yang baik (good character) berlandaskan kebajikan-kebajikan inti (core virtues) yang secara obyektif baik bagi individu maupun masyarakat.

\section{B. Fungsi Pendidikan Karakter}

Menurut Gunawan (2012

Pendidikan Karakter berfungsi :

1. Mengembangkan potensi dasar agar berhati baik, berpikiran baik, dan berperilaku baik.

2. Memperkuat dan membangun perilaku bangsa yang multikultur,

3. Meningkatkan peradaban bangsa yang kompetitif dalam pergaulan dunia.

Sedangkan Menurut Badan Penelitian dan Pengembangan Pusat Kurikulum Kementerian Pendidikan Nasional tentang Pengembangan Budaya dan Karakter Bangsa/Pedoman Madrasah (Kemendiknas, 2010 :7) bahwa Fungsi pendidikan karakter adalah: (1) Pengembangan: pengembangan potensi peserta didik untuk menjadi pribadi berperilaku baik; ini bagi peserta didik yang telah memiliki sikap dan perilaku yang mencerminkan budaya dan karakter bangsa; (2) Perbaikan: memperkuat kiprah pendidikan nasional untuk bertanggung jawab dalam pengembangan potensi peserta didik yang lebih bermartabat; (3) Penyaring: untuk menyaring budaya bangsa sendiri dan budaya bangsa lain yang tidak sesuai dengan nilai-nilai budaya dan karakter bangsa yang bermartabat.

Berdasarkan Panduan Pelaksanaan Pendidikan Karakter Kementerian Pendidikan Nasional (2011 : 3) dijelaskan bahwa Pendidikan karakter berfungsi (1) membangun kehidupan kebangsaan yang multikultural; (2) membangun peradaban bangsa yang cerdas, berbudaya luhur, dan mampu berkontribusi terhadap pengembangan kehidupan ummat manusia; mengembangkan potensi dasar agar berhati baik, berpikiran baik, dan berperilaku baik serta keteladanan baik; (3) membangun sikap warganegara yang cinta damai, kreatif, mandiri, 
dan mampu hidup berdampingan dengan bangsa lain dalam suatu harmoni.

\section{Tujuan Pendidikan Karakter}

Di dalam pasal 2 point a,b,c Peraturan Presiden nomor 87 tahun 2017 tentang penguatan pendidikan karakter (PPK), tujuan PPK adalah:

a. Membangun dan membekali Peserta Didik sebagai generasi emas Indonesia Tahun 2045 dengan jiwaPancasila dan pendidikan karakter yang baik guna menghadapi dinamika perubahan di masa depan;

b. Mengembangkan platform pendidikan nasional yang meletakkan pendidikan karakter sebagai jiwa utamadalam penyelenggaraan pendidikan bagi Peserta Didik dengan dukungan pelibatan publik yang dilakukan melalui pendidikan jalur formal, nonformal, dan informal dengan memperhatikan keberagaman budaya Indonesia; dan

c. Merevitalisasi dan memperkuat potensi dan kompetensi pendidik, tenaga kependidikan, Peserta didik, masyarakat, dan lingkungan keluarga dalam mengimplementasikan PPK. (Pepres nomor 87, $2017: 4$ )

Menurut Muslich (2011: 81) Pendidikan Karakter bertujuan untuk meningkatkan mutu penyelenggaraan dan hasil pendidikan yang mengarah pada pencapaian pembentukan karakter dan akhlak mulia peserta didik secara utuh, terpadu dan seimbang. Melalui Pendidikan karakter diharapkan peserta didik mampu secara mandiri meningkatkan dan menggunakan pengetahuannya, mengkaji dan menginternalisasi, serta mempersonalisasi nilainilai karakter dan akhlak mulia sehingga terwujud dalam perilaku sehari-hari.

Menurut Fitri (2012 : 22) menyatakan bahwa Pendidikan karakter bertujuan membentuk dan membangun pola pikir, sikap, dan perilaku peserta didik agar menjadi pribadi yang positif, berakhlak karimah, berjiwa luhur, dan bertanggung jawab.Secara substantif, tujuan pendidikan karakter adalah membimbing dan memfasilitasi anak agar memiliki karakter positif (baik).

\section{Nilai-nilai dalam Pendidikan Karakter}

Nilai-nilai yang dikembangkan dalam pendidikan karakter diidentifikasi dari sumbersumber berikut ini.

1. Agama: masyarakat Indonesia adalah masyarakat beragama. Oleh karena itu, kehidupan individu, masyarakat, dan bangsa selalu didasari pada ajaran agama dan kepercayaannya. Secara politis, kehidupan kenegaraan pun didasari pada nilai-nilai yang berasal dari agama. Atas dasar pertimbangan itu, maka nilai-nilai pendidikan budaya dan karakter bangsa harus didasarkan pada nilainilai dan kaidah yang berasal dari agama.

2. Pancasila: negara kesatuan Republik Indonesia ditegakkan atas prinsip-prinsip kehidupan kebangsaan dan kenegaraan yang disebut Pancasila. Pancasila terdapat pada Pembukaan UUD 1945 dan dijabarkan lebih lanjut dalam pasal-pasal yang terdapat dalam UUD 1945. Artinya, nilai-nilai yang terkandung dalam Pancasila menjadi nilainilai yang mengatur kehidupan politik, hukum, ekonomi, kemasyarakatan, budaya, dan seni. Pendidikan budaya dan karakter bangsa bertujuan mempersiapkan peserta didik menjadi warga negara yang lebih baik, yaitu warga negara yang memiliki kemampuan, kemauan, dan menerapkan nilainilai Pancasila dalam kehidupannya sebagai warga negara.

3. Budaya: sebagai suatu kebenaran bahwa tidak ada manusia yang hidup bermasyarakat yang tidak didasari oleh nilai-nilai budaya yang diakui masyarakat itu. Nilai-nilai budaya itu dijadikan dasar dalam pemberian makna terhadap suatu konsep dan arti dalam komunikasi antaranggota masyarakat itu. Posisi budaya yang demikian penting dalam kehidupan masyarakat mengharuskan budaya menjadi sumber nilai dalam pendidikan budaya dan karakter bangsa.

4. Tujuan Pendidikan Nasional: sebagai rumusan kualitas yang harus dimiliki setiap warga negara Indonesia, dikembangkan oleh berbagai satuan pendidikan di berbagai jenjang dan jalur. Tujuan pendidikan nasional memuat berbagai nilai kemanusiaan yang harus dimiliki warga negara Indonesia. Oleh karena itu, tujuan pendidikan nasional adalah sumber yang paling operasional dalam pengembangan pendidikan budaya dan karakter bangsa.

\section{E. Prinsip Pengembangan Pendidikan Karakter}

Pada prinsipnya, pengembangan karakter tidak dimasukkan sebagai pokok bahasan tetapi terintegrasi ke dalam mata pelajaran, pengembangan diri, dan budaya Madrasah. Oleh 
karena itu, guru dan Madrasah perlu mengintegrasikan nilai-nilai yang dikembangkan dalam pendidikan karakter dalam Kurikulum, Silabus dan Rencana Program Pembelajaran (RPP) yang sudah ada. Prinsip pembelajaran yang digunakan dalam pengembangan pendidikan budaya dan karakter bangsa mengusahakan agar peserta didik mengenal dan menerima nilai-nilai budaya dan karakter bangsa sebagai milik mereka dan bertanggung jawab atas keputusan yang diambilnya melalui tahapan mengenal pilihan, menilai pilihan, menentukan pendirian, dan selanjutnya menjadikan suatu nilai sesuai dengan keyakinan diri. Dengan prinsip ini, peserta didik belajar melalui proses berpikir, bersikap, dan berbuat.Ketiga proses ini dimaksudkan untuk mengembangkan kemampuan peserta didik dalam melakukan kegiatan sosial dan mendorong peserta didik untuk melihat diri sendiri sebagai makhluk sosial.

\section{F. Pendekatan dan Metode dalam Pendidikan Karakter}

\section{Pendekatan Pendidikan Karakter}

Berbicara mengenai pendekatan dalam pendidikan karakter terdapat beberapa ahli yang memberikan pendapatnya seperti yang dikemukakan oleh Ardy Wiyani (2012 : 27) bahwa " ada 3 jenis pendekatan pendidikan karakter yaitu: (1) Pendekatan komprehensif; (2) Pembelajaran Terintegrasi; (3) Pengembangan Kultur Madrasah

\section{Metode Pendidikan Nilai Karakter}

Menurut Saleh (2011 : 12) metode dalam pendidikan Karakter Bangsa antara lain dengan cara: (a) Melalui Keteladanan; (b) Melalui Simulasi Praktek; (c) Menggunakan metode ikon dan afirmasi (menempel dan menggantung); (d) Metode Repeat Power; (e) Metode 99 Sifat Utama; (f) Membangun Kesepakatan Nilai Keunggulan; (g)Melalui Penggunaan Metafora.

\section{G. Indikator Keberhasilan Madrasah dan Kelas dalam Pendidikan Karakter}

Menurut Hasan dkk, (Fitri, 2012 :39) ada dua jenis indikator yang ingin dikembangkan terkait pendidikan Nilai-Nilai Karakter dan Budaya Bangsa yaitu Indikator untuk Madrasah dan kelas. Indikator Madrasah dan kelas adalah penanda yang digunakan oleh Kepala Madrasah, guru dan personalia Madrasah dalam merencanakan, melaksanakan dan mengevaluasiMadrasah sebagai lembaga pelaksana pendidikan Nilai karakter dan budaya bangsa.Indikator ini berkenaan juga dengan kegiatan Madrasah yang diprogramkan dan kegiatan Madrasah sehari-hari (rutin). Indikator dirumuskan dalam bentuk perilaku peserta didik di kelas dan Madrasah yang dapat diamati melalui pengamatan guru ketika seorang peserta didik melakukan suatu tindakan di Madrasah, tanya jawab dengan peserta didik, jawaban yang diberikan peserta didik terhadap tugas dan pertanyaan guru, serta tulisan peserta didik dalam laporan dan pekerjaan rumah. Indikator berfungsi bagi guru sebagai kriteria untuk memberikan pertimbangan tentang perilaku untuk nilai tertentu telah menjadi perilaku yang dimiliki peserta didik.

\section{METODE}

Jenis penelitian yang digunakan adalah kualitatif. Metode penelitian yang dilakukan adalah deskriptif kualitatif yang bertujuan untuk memberikan gambaran tentang Implementasi Penguatan Pendidikan Karakter di MTs Negeri 1 Jeneponto. Lokasi penelitian ini adalah pada MTs Negeri 1 Jenepontodi Kabupaten Jeneponto. Yang menjadi sasaran penelitian ini adalah Kepala Madrasah, Guru dan Siswa pada MTs Negeri 1 Jeneponto. Adapun yang menjadi fokus penelitian adalah: (1) Proses pengintegrasian pendidikan karakter ke dalam mata pelajaran pada MTs Negeri 1 Jeneponto; (2) Penguatan Pendidikankarakter ke dalam pengembangan diri siswa pada MTs Negeri 1 Jeneponto; (3) Faktor pendukung dan penghambat dalam pelaksanaan penguatan pendidikankarakter pada MTs Negeri 1 Jeneponto.

Untuk memudahkan pemahaman tentang fokus penelitian, maka penulis akan menguraikan lebih jelas maksud yang dikehendaki dalam penelitian ini yaitu Implementasi Penguatan Pendidikan Karakter pada MTs Negeri 1 Jeneponto.

1. Proses penguatan pengintegrasian Pendidikan Karakter ke dalam mata pelajaran adalah proses dimana seorang guru mata pelajaran melakukan pengintegrasian pendidikan nilai karakter ke dalam mata pelajaran yang nampak pada perangkat pembelajaran seperti silabus dan RPP (Rencana Pelaksanaan Pembelajaran) 
2. Pengembangan diri merupakan rangkaian kegiatan siswa yang dilakukan diluar kegiatan pembelajaran di kelas dalam bentuk kegiatan ekstrakurikuler seperti pramuka, bimbingan kerohanian, latihan ceramah/pidato, paskibra, drum band dan sanggar seni

3. Faktor pendukung merupakan semua hal yang ikut memberi dukungan positif terhadap pelaksanaan pendidikan nilai-nilai karakter pada MTs Negeri 1 Jeneponto, sedngkan faktor penghambat merupakan semua yang dianggap kendala di dalam pelaksanaan pendidikan nilai-nilai karakter pada MTs Negeri 1 Jeneponto.

Sumber data dalam penelitian ini adalah Kepala Madrasah dan guru- guru yang mengajar di MTs Negeri 1 Jeneponto yang berjumlah 14 orang guru sesuai dengan banyaknya jumlah mata pelajaran serta perwakilan lima orang siswa setiap kelas dari 25 kelas.

Untuk menjaga obyektivitas penelitian, sebagai instrumen maka yang digunakan adalah peneliti sendiri, pedoman wawancara, catatan dokumentasi, lembar observasi sebagai penuntun mengajukan pertanyaan tentang Implementasi Pendidikan Karakter di MTs Negeri 1 Jeneponto.

Tehnik pengumpulan data yang digunakan dalam penelitian ini adalah: (1) Melakukan wawancara mendalam tentang proses pengintegrasian pendidikan karakter ke dalam mata pelajaran, implementasi pendidikan karakter ke dalam mata pelajaran serta hasil pengimplementasian pendidikan karakter; (2) Mengkaji dokumentasi guru dengan melihat perangkat pembelajaran meliputi silabus dan RPP; (3) Melakukan observasi atau pengamatan terhadap guru pada saat mengajar.

Dalam Penelitian ini teknik pengabsahan data yang dilakukan adalah dengan cara triangulasi dan member check. Triangulasi data yang dilakukan adalah dengan cara menanyakan hal yang sama dengan sumber yang berbeda. Sumber-sumber tersebut adalah pihak yang terkait dan berhubungan dengan Implementasi Pendidikan Karakter pada MTs Negeri 1 Jeneponto.

\section{HASIL DAN PEMBAHASAN}

\section{A. Gambaran Umum Lokasi Penelitian}

Lokasi penelitian ini adalah pada MTs Negeri 1 Jenepontodi Kabupaten Jeneponto. Tepatnya di Jalan Lanto Dg Pasewang No.349
Telp. 0419- 21186 Kelurahan Balang Kabupaten Jeneponto.

\section{B. Hasil Penelitian}

\section{Implementasi Penguatan Pendidikan Nilai-Nilai Karakter Melalui Pengintegrasian Ke dalam Mata Pelajaran Agama dan PPKn di MTs Negeri 1 Jeneponto.}

Implementasi pendidikan nilai karakter dalam Pengintegrasian Ke dalam Mata Pelajaran Agama dan PPKn di MTs Negeri 1 Jeneponto sangat bisa membantu untuk mencapai tujuan dari pendidikan. proses belajar mengajar dapat tercapai dengan maksimal dengan adanya tes awal agar para tenaga pendidik mampu memberikan semangat atau motivasi lebih terhadap para peserta didik dengan harapan mereka mampu melaksanakan pembelajaran dengan baik.

Implementasi pada pendidikan karakter dalam mata pelajaran PPKn dan Pendidikan agama dalam kehidupan keseharian para peserta didik, sikap kejujuran merupakan hal yang paling mutlak di tunjukkan di kehidupan sosialnya. Dari bentuk sikap kejujuran yang terbangun oleh para peserta didik di kehidupan mereka, maka hal inilah yang menunjukkan bahwa proses pembelajaran pendidikan karakter mampu menanamkan sikap jujur oleh para peserta didik. Dalam pengimplementa pendidikan karakter di mata pelajaran agama,ada hal menjadi penguat dalam mencapai tujuan. implementasi pendidikan karakter di MTs Negeri 1 Jeneponto harus membentuk karakter para peserta didik untuk cinta tanah air. Hal ini dikarenakan dengan rasa cinta terhadap tanah air yang tertanam pada peserta didik, maka jiwa nasionalisme dari para siswa bisa menjadi modal dalam pengembangan karakter mereka di kehidupan keseharian mereka. Dalam impelementasi pendidikan karakter pada mata pelajaran PPKn, penguatan materi sangat menentukan untuk tercapainya pendidikan karakter yang sesuai dengan tujuannya. terkait dengan penguatan pendidikan karakter pada mata pelajaran PPKn di MTs Negeri 1 Jeneponto adalah seorang tenaga pendidik harus mampu memberikan pemahaman kepada para peserta didik yang lebih mengarah kepada proses kehidupan para peserta didik. Hal ini bertujuan agar para peserta didik lebih cepat memahami tentang implementasi pendidikan karakter langsung. Kehidupan sosial mereka akan 
jauh lebih muda mereka pahami dan dengan cara para tenaga pendidik memaparkan kepada peserta didik, maka mereka akan jauh lebih muda mencerna inti dan tujuan dari pendidikan karakter yang ada pada saat ini.

Ada hal yang harus dipersiapkan oleh para tenaga pendidik dalam setiap mata pelajaran yang di bawakan. Dalam mata pelajaran agama, perangkat pembelajaran atau Silabus dan RPP begitu penting dalam proses belajar mengajar untuk mencapai tujuan pembelajaran terkhsus untuk pembahasan tentang pendidikan karakter dalam mata pelajaran agama. para pendidik harus menyiapkan perangkat pembelajaran yang lebih menanamkan pada muatan afektif, jangan hanya terpaku pada kognitif. Hal ini didasari pada perkembangan dunia pendidikan yang sudah masuk di era revolusi mental 4.0. Penguatan dalam pendidikan karakter itu sangat di butuhkan oleh para peserta didik untuk mencapai apa yang menjadi tujuan dalam proses pembelajaran. setiap proses pembelajaran, terkhusus untuk mata pelajaran PPKn, setiap tenaga pendidik wajib untuk member penguatan terhadap para peserta didik. Hal inilah yang menjadi bentuk penyemangat kepada mereka agar mampu fokus dan bisa memahami pelajaran yang diberikan. Dalam hal ini para peserta didik harus memberikan penguatan seperti dengan pujian, memberikan motivasi untuk bisa memahami arti dari pendidikan karakter dan mampu memberikan sebuah penghargaan kepada para peserta didik. Hal inilah yang sangat membantu para peserta didik untuk mencapai tujuan yang kita harapkan.

\section{Implementasi Penguatan Pendidikan Nilai-Nilai Karakter Melalui Pengembangan Diri di MTs Negeri 1 Jeneponto}

Madrasah adalah salah satu lembaga pendidikan Islam yang penting di Indonesia selain pesantren. Keberadaannya begitu penting dalam menciptakan kader-kader bangsa yang berwawasan keislaman, berkarakter dan berjiwa nasionalisme yang tinggi. Salah satu kelebihan yang dimiliki madrasah adalah adanya integrasi ilmu umum dan ilmu agama.Madrasah diharapkan menjadi salah satu lembaga pendidikan yang mampu melahirkan generasi bangsa yang ahli ilmu (ilmuan), dan ilmuan yang beragama yang kuat (ulama).

Dengan kata lain mampu mencetak generasi bangsa yang ilmuan yang ulama dan ulama yang ilmuan Dan berahlak mulia serta memiliki karakter yang mandiri dan disiplin. penanaman nilai karakter pada mata pelajaran PPKn terhadap para peserta didik di MTs Negeri 1 Jeneponto mampu mengajarkan bahwa pengintegrasian dalam suatu wilayah bisa kita satukan. Dalam hal ini adalah walaupun kita berbeda dari tatanan agama, suku maupun budaya tapi kita dapat dipersatukan oleh Bhineka Tunggal Ika. Di sisi lain kita bisa melihat dampak langsung dari pendidikan karakter terhadap para peserta didik. tentang dampak langsung yang dirasakan oleh para peserta didik dengan pembelajaran pendidikan karakter adalah dapat kita lihat dari bentuk keseharian para peserta didik. Dari bentuk tingkah laku mereka, kita dapat menilai bentuk dari dampak dari proses pendidikan karakter yang dilakukan oleh para peserta didik yang ada di MTs Negeri 1 Jeneponto.

Dalam pencapaian pendidikan karakter dalam keseharian di sekolah, harus menggunakan metode ataupun cara dalam pengimplementasian. pendidikan di MTs Negeri 1 Jeneponto, ada banyak motede yang bisa kita gunakan dalam prosesi pembelajaran. Salah satunya adalah para tenaga pendidik harus menyiapkan strategi untuk mampu menyalurkan konsep pendidikan karakter terhadap para peserta didik. Implementasi penguatan pendidikan karkter yang di terapkan di MTs Negeri 1 Jeneponto, ada hal yang menjadi titik fokus dalam pencapaiannya. para tenaga pendidik yang ada di MTs Negeri 1 Jeneponto harus mampu memberikan contoh tentang nilai karakter yang ada. Menanamkan nilai rasa nasionalisme sangat bermanfaat untuk bisa membuat para siswa mampu menghargai di kehidupan sosial maupun di kehidupan bermasyarakat.

Dengan adanya implementasi penguatan pendidikan karakter di MTs Negeri 1 Jeneponto, banyak hal yang dirasakan oleh para tenaga pendidik. implementasi pendidikan karakter para peserta didik pada mata pelajaran PPKn yang ada di MTs Negeri 1 Jeneponto, para peserta didik mengalami peningkatan dalam proses pembelajarannya. Hal ini tidak terlepas dari apa yang dilakukan oleh bapak Rusdi untuk memberikan gambaran kepada para peserta didik tentang kehidupan sosial mereka dan para peserta didik jauh lebih memamhami dan mampu mencerna implementasi pada pendidikan karakter. Prose untuk mencapai tujuan pendidikan karakter adalah dengan memberikan pemahaman tentang nilai-nilai pancasila. dalam 
proses pembelajaran yang dilakukan di kelas, para tenaga pendidik harus mampu menanmkan nilai-nilai pancasila kepada para eserta didik. Ini dikarenakan agar para peserta didik mampu memahami dan mengimplementasikan nilai-nilai pancasila di kehidupan mereka sehari-hari.

Penguatan pendidikan karakter di MTs Negeri 1 Jeneponto, harus memiliki program untuk mencapai pendidikan yang kita harapkan. dalam melaksanakan proses pendidikan karakter terkhusus untuk mata pelajaran PPKn di MTs Negeri 1 Jeneponto, harus melaksanakan program penddikan yang sudah menjadi barometer dalam pendidikan yang ada di sekolah. Hal inilah yang mampu membentuk karakter para peserta didik untuk mampu mengaktualisasikan apa yang mereka dapatkan di sekolah. Untuk mencapai tujuan dari implementasi pendidikan karakter, peran siswa sebagai peserta didik menjadi kunci kesuksesan sebuah kegiatan belajar mengajar. pendidikan karakter yang di terapkan di sekolah MTs Negeri 1 Jeneponto sangat membantu para peserta didik untuk membentuk karakter yang jauh lebih baik lagi. Hal ini dapat dirasakan langsung oleh para peserta didik dimana mereka dapat merasakan arti dari saling menghargai, sikap bertanggung jawab dan masih banyak hal yang lain yang di dapatka oleh para peserta didik selama mengikuti proses pembelajaran pendidikan karakter.

\section{Faktor Pendukung dan Penghambat Dalam Pelakasanaan Penguatan Pendidikan Karakter di MTs Negeri 1 Jeneponto.}

Pendidikan karakter pada tingkatan institusi mengarah pada pembentukan budaya sekolah, yaitu nilai-nilai yang melandasi perilaku, tradisi, kebiasaan keseharian, dan simbol-simbol yang dipraktikkan oleh semua warga sekolah, dan masyarakat sekitar sekolah. Budaya sekolah merupakan ciri khas, karakter atau watak, dan citra sekolah tersebut di mata masyarakat luas. Dalam proses pembelajaran, selalu ada hal yang menjadi faktor pendukung maupun faktor penghambat untuk mencapai tujuan dari pendidikan yang ada di Indonesia. proses pembelajaran PPKn, ada faktor penghambat untuk mencapai tujuan pembelajaran adalah para peserta didik masih belum bisa memahami tentang moral yang ada pada lingkungan sekolah. Hal inilah yang menjadi tugas para peserta didik untuk memberikan pemahaman yang lebih kepada peserta didik. Di sisi lain para peserta didik belum mampu untuk saling menghargai baik itu antar sesame siswa maupun dengan para guru. Hal inilah yang menjadi salah satu bentuk penghambat tercapainya pendidikan yang ingin di harapkan. Di sisi lain faktor pendukung dalam proses pembelajaran PPKn adalah para peserta didik sangat memiliki jiwa sosidaritas yang begitu tinggi dan inilah bisa di lihat ketika ada bentuk kerja sama yang lahir pada peserta didik.

Dalam implementasi pendidikan karakter ada banyak hal yang membuat proses tersebut menjadi kendala dalam mencapai tujuan. kendala yang di hadapi adalah dengan kurikulum dalam pendidikan yang ada di MTs Negeri 1 Jeneponto memiliki muatan yang belum mampu di implementasikan oleh para tenaga pendidik yang ada. Hal yang menjadi penghambat adalah proses transformasi pertumbuhan yang di alami oleh para peserta didik sehingga terkadang hal ini membutuhkan proses atau metode khusus untuk bisa mencapai tujuan dari implementasi pendidikan karakter. Selain hal yang menghambat, ada juga faktor yang menjadi pendukung dalam pendidikan karakter. implementasi pendidikan karakter pada mata pelajaran agama, sangat membantu para peserta didik mengubah etika dalam kehidupan bermasyarakat. Sehingga dalam keseharian, mereka terlihat lebih santun dan lebih saling menghargai dalam kehidupan sosial terutama dalam kehidupan di ruang lingkup keluarganya.

Dalam peningkatan pendidikan di MTs Negeri 1 Jeneponto, ada beberapa kendala yang terkadang menghambar tercapainya tujuan pendidikan terkhusus untuk pendidikan karakter di mata pelajaran PPKn. kendala untuk mencapai tujuan dari pendidikan karakter di MTs Negeri 1 Jeneponto tidak terlepas dari bentuk perkembangan zaman dan kemajuan teknologi. Disisi lain, majunya teknologi tidak didasari dari bentuk kesadaran para siswa.

\section{Pembahasan}

\section{Implementasi Penguatan Pendidikan Nilai-Nilai Karakter Melalui Pengintegrasian Ke dalam Mata Pelajaran Agama dan PPKn}

Dalam penguatan pendidikan karakter di MTs Negeri 1 Jeneponto kedalam mata pelajaran PPKn dan agama, proses pembelajaran dapat tercapai dengan adanya tes lebih awal yang 
dilakukan oleh para tenaga pendidik dan memberikan bentuk motivasi terhadap seluruh peserta didik. Hal ini dikarenakan untuk mencapai tujuan dari implementasi pendidikan karekter yang kita harapkan. Memberikan motivasi kepada peserta didik diharapkan untuk memberikan sengat yang lebih terhadap siswa demi kelancaran proses pembelajaran yang ada.

Di sisi lain untuk mencapai tujuan pendidikan karakter para tenaga pendidik juga harus mempu menanamkan nilai-nilai kejujuran terhadap peserta didik. Dari bentuk kejujuran yang kita tanamkan kepada para peserta didik, maka kita bisa berharap dengan implementasi pendidikan karakter nilai kejujuran yang ada pada peserta didik mampu di terapkan di ruang lingkup keluarga maupun di kehidupan sosial mereka. Selain penanaman nilai-nilai kejujuran yang ditanamkan oleh para peserta didik, para tenaga pendidik juga harus menjelaskan bentuk rasa cinta tanah air dan nilai nasionalisme kepada peserta didik. Rasa cinta tanah air kita harapkan untuk menjadi modal dalam pengembangan karakter mereka di kehidupan keseharian para siswa. Rasa nasionalisme yang ada pada peserta didik mampu membangun kebersamaan yang bisa terjalin antar sesame siswa maupun para tenaga pendidik. Nasionalisme dan Cinta tanah air adalah salah satu bentuk kunci untuk mencipkan karakter yang kuat bagi para peserta didik yang ada di MTs Negeri 1 Jeneponto. Selain menanamkan rasa nasionalisme dan cinta tanah air kepada para peserta didik, para tenaga pendidik juga harus mampu untuk memberikan contoh inspiratif kepada mereka. Contoh inspiratif yang dapat diberikan kepada para peserta adalah memberikan gambaran kehidupan sosial dan kehidupan keluarga mereka yang berkaitan tentang pendidikan karakter, karena dengan memberikan contoh yang bersentuhan langsung dengan mereka yakin mereka pasti akan bisa jauh lebih memahaminya.

Selain itu, dalam pencapaian pendidikan karakter yang diterapkan pada mata pelajaran PPKn dan Agama di MTs Negeri 1 Jeneponto, preoses pembelajaran harus menjadi fokus. Dalam hal ini perangkat pembelajaran yang harus kita persiapkan, seperti silabus dan RPP harus kita berikan muatan tentang pendidikan karakter dan implementasinya. Dalam perencanaan perangkat pembelajaran, para peserta didik harus memberikan fokus pafa rana afektif dan bukan hanya pada rana kognitif. Hal inilah yang menjadi barometer implementasi pendidikan karakter pada peserta didik. Pada rana afektif dan kognitif sangat memberikan pengaruh terhadap perkembangan pendidikan yang ada pada mata pelajaran PPKn di MTs Negeri 1 Jeneponto. Hal inilah yang menjadi barometer dalam perkembangan pendidikan dalam era revolusi mental 4.0 yang di gaungkan oleh pemerintah untuk saat ini. Dalam pencapaian tujuan dari implementasi pendidikan karakter kuncinya adalah bagaimana kita mampu memberikan bentuk motivasi belajar kepada para peserta didik untuk senantiasa meningkatkan minat belajar mereka. Saah satu contoh untuk memberikan motivasi mereka adalah dengan cara memberikan pujian kepada siswa, memberikan reward atau penghargaan kepada siswa agar mereka bisa termotivasi dalam proses pembelajaran.

\section{Implementasi Penguatan Pendidikan Nilai-Nilai Karakter Melalui Pengembangan Diri}

Dalam penguatan nilai-nilai karakter dalam pengembangan diri peserta didik dalam pengembangan diri di MTs Negeri 1 Jeneponto adalah kita mampu memberikan wawasan kebangsaan dan keagamaan yang ada kepada para peserta didik. Disisi lain kita harapkan lembaga pendidikan yang mampu melahirkan generasi bangsa yang ahli ilmu (ilmuan), dan ilmuan yang beragama yang kuat. Dalam penguatan pendidikan nilai karakter para peserta didik, para peserta didik harus mampu memberikan penguatan untuk memahami makna dari ideologi Negara Republik Indonesia yaitu Pancasila. Pancasila merupakan dasar dari segala falsafah bangsa. Semua untuk pendidikan yang ada saat ini merupakan bentuk dari pengembangan keilmuan dan bertujuan untuk mencerdaskan kehidupan bangsa. Para tenaga pendidik harus mampu menjelaskan tentang makna Bhineka Tunggal Ika. Hal ini di karenakan di MTs Negeri 1 Jeneponto mempunyai keberagaman suku. Oleh karena itu penguatan pemahaman nilai karakter terhadap para siswa dapat kita harapkan untuk tercapainya tujuan pendidikan karakter yang ada di MTs Negeri 1 Jeneponto.

Dalam proses penguatan nilai karakter terhadap peserta didik di MTs Negeri 1 Jeneponto, proses pembelajaran yang di terapkan oleh para tenaga pendidik tidak terlepas dari bentuk sikap dan etika para peserta didik yang ada di MTs Negeri 1 Jeneponto. Dalam hal ini bisa kita katakana bahwa pendidikan karakter yang ada di sekolah akan berdampak langsung 
kepada seluruh peserta didik di keseharian mereka. Untuk mencapai penguatan pada nilai karakter di MTs Negeri 1 Jeneponto, para peserta didik harus mampu memberikan metode ataupun teknik dalam proses pembelajaran. Dalam penerapan pendidikan karakter para guru harus mempu menggunakan metode ataupun strategi pendekatan konseptual. Hal ini dikarenakan menggunakan strategi yang dapat mengajak para peserta didik untuk mampu memandang kehidupan sosial mereka dan para tenaga pendidik harus mampu mengaitkan kondisi sosial mereka dengan pendidikan nilai karakter. Dengan menggunakan metode ini, para peseta didik lebih muda dan gampang untuk memahami proses penanaman nilai dalam pendidikan karakter.

Hal yang lain dalam meningkatkan penanaman nilai pada pendidikan karakter, para tenaga pendidik juga harus mampu memberikan contoh kepada para peserta didik. Seperti penjelasan tentang patriotism yang ada di masyarakat. Karena dengan penjelasan contoh dari kehidupan mereka, para siswa akan lebih muda untuk menganalisis penguatan nilai pendidikan karakter yang ada di kehidupan sosial para peserta didik. Rasa patriotism yang di tanamkan kepada seluruh peserta didik mampu mengubah perilaku dan para peserta didik bisa lebih menghargai antar sesama baik itu yang ada di lingkungan sekolah maupun yang ada di lingkungan masyarakat. Peningkatan nilai pendidikan karakter para peserta didik di MTs Negeri 1 Jeneponto harus mampu membuat mereka merasa nyamman dan menikmati proses pembelajaran yang ada sehingga proses pembelajaran harus di buat nyaman oleh para tanaga pendidik dengan cara mampu menggunakan metode atau model pembelajaran yang gampang di cernah oleh para peserta didik. Proses untuk mecapai penguatan nilai karakter adalah para tenaga didik harus menuangkan nilainilai pancasila dalam setiap metode pembelajarannya. Dalam pelaksanaan proses pembelajaaran pendidikan yang sudah dicanangkan sekolah seperti pembiasaanpembiasaan budaya, penanaman nilai-nilai religius dan memberikan sanksi dan tindak lanjut kepada siswa yang melakukan pelanggaran. Dengan bentuk sistem penegasan dalam proses pembelajaran, maka salah satu dari bentuk nilai karakter telah di Implementasikan dalam proses pembelajaran. Hal ini didasari agar para peserta didik mampu menanamkan nilai-nilai pancasila dalam keseharian mereka. Karena nilai pancasila merupakan kunci dari proses pendidikan karakter yang ada.

\section{Faktor Pendukung dan Penghambat dalam Pelakasanaan Penguatan Pendidikan Karakter}

Pendidikan karakter pada tingkat sekolah menengah atau pada tatanan SMP merupakan hal yang paling urgen dalam setiap pembahasan. Hal ini disebabkan oleh pembentukan karakter dan proses pendewasaan yang dialami oleh para peserta didik. Perilaku yang ditonjolkan oleh para peserta didik mempu menjadi cerminan tentang sifat ataupun karakter yang dimiliki. Hal inilah yang menjadi acuan para tenaga pendidik untuk mampu membentuk karakter peserta didik menjadi lebih baik lagi. Dalam proses pembentukan karakter khususnya yang ada di MTs Negeri 1 Jeneponto, ada banyak hal yang menjadi faktor penghambat dan pendukung untuk mencapai tujuan dari pembelajaran tersebut. Hal yang biasa di jumpai oleh para tenaga pendidik adalah masih dominan para peserta didik yang belum mampu memahami arti dari moralitas dan saling menghargai. Hal iniah yang membuat para tenaga didik harus bekerja untuk mampu memberikan pemahaman kepada seluruh peserta didik tentang arti dari sikap saling menghargai dan saling menghormati. Di sisi lain kendala dalam mencapai tujuan pendidika karakter adalah muatan kurikulum yang ada di MTs Negeri 1 Jeneponto masih banyak dari para peserta didik belum mampu di implementasikan dengan baik oleh para peserta didik. Hal ini di sebabkan karena para peserta didik mengalami proses tranformasi dari masa anak-anak ke remaja sehingga ini membutuhkan cara atau proses tersendiri untuk bisa menghandel para peserta didik di sekolah. Proses peralihan inilah yang membuat para tenaga pendidik harus mampu memahami karakter di setiap peserta didik sehingga proses pembelajaran pendidikan karakter dapat berjalan dengan maksimal dan mencapai tujuan yang diharapkan. Selain muatan kurikulum yang menjadi kendala, hal lain yang menjadi penghambat untuk tercapainya tujuan pendidikan karakter di MTs Negeri 1 Jeneponto adalah Perkembang pesatnya teknologi terutama dalam bidang informasi sehingga banyak dari peserta didik terkadang mencontoh hal-hal yang bisa dikatakan kurang baik atau mengarah ke hal negativ. Hal ini banyak kita dapati seperti contoh dari segi berpakaian, segi berbicara dengan para guru dan yang paling sering kita dapati banyakna 
peserta didik dengan gampangnya membuka situs negativ yang ada di smartphone mereka.

Kendala yang didapatkan oleh para tenaga pendidik di MTs Negeri 1 Jeneponto adalah ketika para tenaga pendidik menanamkan rasa nilai cinta terhadap pancasila banyak peserta didik belum mampu mencerna makna dari nilai pancasila tersebut. Dari sinilah proses dan metode pembelajaran yang di terapkan oleh para tenaga pendidik harus dengan mudah di terima dan dipahami oleh para peserta didik. Di sisi lain Kendala dalam mengajarkan pendidikan karakter adalah latar belakang para peserta didik itu sendiri yang minat belajarnya bisa kita katakana kurang serta dampak dari globalisasi sehingga peserta didik kurang fokus dalam proses pembelajaran. Latar belakang dari para peserta didik sangat berpengaruh untuk mencapai tuuan dari pendidikan karakter yang ada di MTs Negeri 1 Jeneponto.

Selain dari faktor penghambat dalam proses pendidikan karakter di MTs Negeri 1 Jeneponto, ada juga faktor pendukungnya yaitu ketika dalam mata pelajaran agama para peserta didik mampu memperlihatkan bentuk dari kekompakan yang dibangun di dalam kelas. Hal inilah yang membuat nilai toleransi terhadap para peserta didik tertanan pada mereka. Dengan adanya nilai toleransi antar para peserta didik menjadi hal yang mendasar untuk mencapai tujuan dari pendidikan karakter yang ada di MTs Negeri 1 Jeneponto. Di sisi lain dalam proses pembelajaran hal yang mampu memberikan dukungan dalam proses pembelajan adalah bentuk dari tingginya solidaritas dalam setiap kegiatan pembelajaran. Dari sinilah peran penting dari tenaga pendidik untuk mampu memberikan semacam pola atau contoh kepada peserta didik untuk mampu memberikan berkomunikasi dengan baik terhadap teman ataupun orang lain.

\section{SIMPULAN DAN SARAN}

Berdasarkan dari hasil penelitan di atas maka peneliti dapat menyimpulkan beberapa hal yaitu :

1. Implementasi penguatan pendidikan nilainilai karakter melalui pengintegrasian ke dalam mata pelajaran Agama dan PPKn di MTs Negeri 1 Jeneponto mencakup beberapa aspek diantaranya adalah
a. Mampu menanamkan nilai-nilai kejujuran terhadap para peserta didik.

b. Membentuk rasa nasionalisme dan cinta tanah air antar sesama.

c. Implementasi Proses pembelajaran pendidikan karakter dalam mencapai tujuannya adalah dengan menyiapkan silabus, RPP dan memperhatikan rana afektif dan koknitif dalam proses pembelajaran.

d. Memberikan motivasi terhadap para peserta didik dan mampu memberikan semacam penghargaan kepada mereka agar mampu meningkatkan minat peserta didik dalam proses pembelajaran.

2. Implementasi penguatan pendidikan nilainilai karakter melalui pengembangan diri di MTs Negeri 1 Jeneponto adalah dengan cara sebagai berikut:

a. Mampu memberikan pemahaman tentang wawasan kebangsaan dan keagamaan terhadap peserta didik dan mampu menjelaskan makna tentang Bhineka Tunggal Ika.

b. Tenaga pendidik mampu menerapkan metode pembelajaran dengan strategi memberikan pemahaman terhadap para peserta didik dengan kehidupan sosial mereka.

c. Tenaga pendidik mampu menanamkan rasa patriotisme terhadap para peserta didik. Hal ini di harapkan agar para peserta didik mampu menjadi panutan dalam lingkup ruang sekolah maupun di masyarakat

3. Faktor pendukung dan penghambat dalam pelakasanaan penguatan pendidikan karakter di MTs Negeri 1 Jeneponto adalah sebagai berikut:

a. Faktor Pendukung

1) Ketika dalam mata pelajaran agama para peserta didik mampu memperlihatkan bentuk dari kekompakan yang dibangun di dalam kelas. Hal inilah yang membuat nilai toleransi terhadap para peserta didik tertanan pada mereka.

2) Tingginya bentuk rasa solidaritas dalam setiap kegiatan pembelajaran yang ada di MTs Negeri 1 Jeneponto.

b. Faktor Penghambat

1) Kurangnya pemahaman para peserta didik tentang moralitas dan saling menghargai.

2) Perkembang pesatnya teknologi terutama dalam bidang informasi sehingga banyak dari peserta didik terkadang mencontoh hal-hal yang 
bisa dikatakan kurang baik atau mengarah ke hal negativ.

3) Peserta didik belum mampu memahami arti dari nilai rasa cinta tanah air.

4) Latar belakang para peserta didik yang berbeda-beda sehingga proses pendidikan implementasi pendidikan karakter bisa terhambat dalam mencapai tujuan yang di inginkan.

Berdasarkan dari kesimpulan di atas, maka peneliti dapat memberikan saran demi kemajuan pendidikan karakter sebagai berikut:

1. Para tenaga pendidik harus mampu mengimplementasian pendidikan karakter dengan baik terhadap para peserta didik dengan cara menyiapkan perangkat pembelajaran, metode pembelajaran yang gampang di cernah oleh para peserta didik.

2. Dalam mauatan kurikulum harus menguatan pembelajaran pendidikan karakter. Hal ini dikarenakan pendidikan karakter di sekolah sangat di butuhkan mengingat perkembangan zaman dan kemajuan ilmu pengetahuan dan teknologi harus di barengi dengan implementasi pendidikan karakter dengan baik di sekolah.

a. Pemerintah harus mampu memperhatikan peningkatan pembelajaran pendidikan karakter sehingga wajib dijadikan sebagai bahan pembelajaran di setiap sekolah di seluruh Indonesia.

\section{DAFTAR RUJUKAN}

Ardy Wiyani, Novan. 2012. Manajemen Pendidikan Karakter Konsep dan Implementasinya Madrasah.Jogyakarta : Pedagogia

Fitri Zaenul, Agus.2012Pendidikan Karakter berbasis Nilai dan Etika di MadrasahJogyakarta : AR-RuzzMedia

Gunawan, H. 2012. Pendidikan Karakter (Konsep dan Implementasi). Bandung:Alfabeta.

Mu'in, Fatchul. 2011.Pendidikan Karakter Konstruksi Teoritik dan Praktik.Jogyakarta : AR-RuzzMedia

Muslich, Masnu $\quad$ Mustari, Mohamad. 2011. Nilai Karakter Refleksi Untuk
Pendidikan Karakter. Jogyakarta : Laksbang Pressindo

Saleh, Muwafik AKH. 2011. Membangun Karakter dengan Hati Nurani PendidikanKarakter Untuk Generasi Bangsa.Malang : Erlangga

Saptono. 2011.Dimensi-dimensi Pendidikan Karakter Wawasan, Strategi, dan Langkah Praktis. Malang : Erlangga

Tohirin. 2011.Metode Penelitian Kualitatif Dalam Pendidikan danBimbinganKonseling.Jakarta : PT. RajaGrafindo Persada

Undang-Undang Nomor 20 Tahun 2003 Tentang Sistem Pendidikan Nasional

Peraturan Presiden Republik Indonesia Nomor 87 Tahun 2017 Tentang Penguatan Pendidikan Karakter (PPK) 